\title{
Cowpea Reaction to Single and Mixed Viral Infection with Blackeye Cowpea Mosaic Virus and Cowpea Yellow Mosaic Virus
}

\author{
*Aliyu, T.H., Balogun, O.S. and Gbadebo, F. M. \\ Department of Crop Protection, Faculty of Agriculture. \\ University of Ilorin, llorin, Kwara State. Nigeria. \\ *Corresponding author: aliyutaiyehussein@yahoo.com
}

\begin{abstract}
Potted experiment was carried out in the screenhouse of the Crop Protection Department, Faculty of Agriculture, University of Ilorin, Nigeria to determine the yield reaction of cowpea to single and mixed viral infection with Blackeye Cowpea Mosaic Virus (BICMV) and Cowpea Yellow Mosaic Virus (CYMV) at different inoculation regimes. The experiment was laid out in a complete randomized block design (CRD). The two viral inoculums (BICMV and CYMV), were mechanically inoculated to cowpea plants, singly and in mixtures at 2 and 4 weeks after planting (WAP). Plants which served as the control were only buffer inoculated. The results of the experiment showed that mixed inoculation with the two viruses, induced greater susceptibility to the viral pathogens in the plants, compared to single virus inoculations. The study also indicated that, early viral infection at 2 WAP, was more pathogenic and resulted in higher yield losses compared with infections at 4 WAP. The findings confirmed that early viral infection in cowpea was more pathogenic than late infection. It also concluded that the synergistic effect of the two viruses when in mixed infection, resulted in higher susceptibility in contrast to single viral infection.
\end{abstract}

Keywords: Cowpea, Viral Inoculum, Blackeye cowpea Mosaic Virus, Cowpea Yellow Mosaic Virus, Single and Mixed Infections, Synergism

\section{INTRODUCTION}

Cowpea, Vigna unguiculata L. (Walp.), is one of the major food legumes cultivated commercially in most tropics and sub-tropics and it is known to provide an important source of protein for the rural poor farmers in developing countries (Bashir et al., 2002). The crop also fixes $80 \%$ nitrogen for its growth demand from the atmosphere (Asiwe et al., 2009). It is also an important companion crop in most cereallegume cropping systems due to the advantages of residual nitrogen, originating from the decay of roots and root nodules (Timko et al., 2007). Cowpeas also increase soil organic matter content and improve soil structure after soil incorporation (Valenzuela and Smith, 2002).

Cowpeas are susceptible to a wide range of pests and pathogens which can cause damage to the crop at all stages of growth (Summerfield and Roberts, 1985). Diseases of cowpea are usually induced by 
viruses, fungi, nematodes, parasitic flowering plants and adverse environmental factors (Davis et al.,1991). Virus diseases are considered to be a major limiting factor for the production of cowpea in the tropical and sub-tropical Countries, and more than 20 viruses are reported from various cowpea-growing areas worldwide (Bashir et al., 2000).

The occurrence of more than one virus specie in a single plant is not uncommon in cultivated plant species, consequently causing a new disease (Murphy and Bowen, 2006 ). Surveys conducted in Kwara State, Nigeria by Aliyu et al. (2012), indicated the presence of viruses in mixed infections on cowpea in the agroecological zones of the State.

Blackeye cowpea mosaic virus (BICMV) occurs wherever cowpea is grown. It is particularly damaging when it occurs in combination with other viruses (Hampton et al., 1997). BICMV infection of some Nigerian commercial cowpea lines can result in a complete loss of yield (Owolabi et al., 1988). In Nigeria, CYMV is considered one of the most important cowpea virus diseases on the basis of its occurrence, epidemic potential, general severity, and the high susceptibility of locally grown cowpea varieties (Thottappilly and Rossel 1992).

Mixed virus infections occur in both plant and animal systems, and doubly infected organisms commonly display increases in disease symptoms and in the accumulation of one or both of the viruses (Pruss et al.,1997). Initial studies in several hosts (pepper, tobacco and Nicotiana benthamiana), have suggested that the interactions can occur at different levels (symptom severity, virus gene expression, replication and movement) and many additional factors such as type and age of host, order of virus arrival can also affect the outcome of the interaction (Méndez-Lozano et al., 2003).

Mixed viral infections in plants may result in a synergistic or antagonistic interactions (Hull, 1977). Antagonism has been found to usually occur when the co-infecting viruses are related, resulting in interference or cross-protection (Sakai et al.,1983; Khan et al.,1994). Synergisms on the other, occur when one virus enhances infection by a distinct or unrelated virus, which implies that protein(s) from one virus can enhance infection by another (Froissart etal., 2002).

In the case of the synergistic interaction, disease complexes elicit symptoms that are more severe than the ones induced individually by the members of the complex. The mechanisms acting in the synergistic interaction are not well understood yet. It has been suggested that the silencing suppressor properties of some geminivirus proteins play an important role. (Vanitharani et al., 2004)

The objectives of the study were to evaluate cowpea reaction to single and mixed viral infections with Blackeye Cowpea Mosaic Virus (BICMV) and Cowpea Yellow Mosaic Virus (CYMV) at two different periods after plant germination.

\section{MATERIALS AND METHODS}

Experimental Design and Agronomic Practices

The experiment was carried out at the screenhouse of the Faculty of Agriculture, University of llorin, located in the Southern Guinea savanna agroecology of Nigeria on latitude $8^{0} 26 \mathrm{~N}$, longitude $4^{\circ} 29 \mathrm{E}$, 
and about $344.7 \mathrm{~m}$ above sea level. The cowpea variety used (Ife Brown) was obtained from the National Seed Council, llorin and the viral inoculums were sourced from infected cowpea leaves obtained from the International Institute of Tropical Agriculture (IITA), Ibadan.

The experimental design was a complete randomized design (CRD) with four-litre plastic pots. The pots were filled with sandy loam soil that was previously steam sterilized at $121^{\circ} \mathrm{C}$ for 120 minutes. Fertilizer application at the rate of $20: 20: 20 \mathrm{Kg} / \mathrm{ha} \mathrm{N}_{2}, \mathrm{P}_{2} \mathrm{O}_{5}$ and $\mathrm{K}_{2} \mathrm{O}$ was done before sowing. Four seeds of the cowpea variety were sown per pot and thinning to two stands each, carried out 7 days after. The viral inoculations were applied singly and in combination, at the 2 and 4 weeks after planting (WAP). Each treatment was thus replicated 4 times, giving a total of 32 pots.

\section{Inoculation Procedure}

The viral isolates were extracted from the infected leaves by homogenization, using mortar and pestle in $0.05 \mathrm{M}$ Phosphate buffer at $\mathrm{pH} 7.2$ at the rate of $1 \mathrm{~g}$ leaf sample to $5 \mathrm{ml}$ of buffer. In all cases, the two plants per pot were mechanically inoculated. The inoculation was done by mechanical transmission of virus through sap. The sap was applied on the surface of the oldest leaves previously sprinkled with carborundum. The sap was applied by gently rubbing the leaves with a cotton wool dipped in the sap. The control plants were buffer inoculated alone, after which all the plants were rinsed with water to reduce inoculation stress on them (Balogun, 2000).

\section{Data Collection}

Data were collected from 2 to 8 weeks after inoculation (WAI) for the following parameters: Plant height, Number of leaves per plant, Number of diseased leaves per plant and number of pods per plant. The percentage disease severity was measured by the number of diseased leaves relative to the total number of leaves on any given plant and expressed as percentage.

\section{Harvesting and Weighing of Seeds}

The cowpea pods harvested at maturity from each plant at 8590 days after planting were sun dried and threshed using pestle and mortar. The weights of pods and seeds were measured using an electronic weighing balance (Model Kerro No. Ka 3002c).

\section{Statistical Analysis}

Data collected on each parameter were subjected to analysis of variance (ANOVA) using the Statistical Package for the Social Sciences SPSS version 15.0. Significant differences among treatment means were separated using New Duncan Multiple Range Test at $5 \%$ level of probability.

\section{Effect on Disease Severity}

\section{RESULTS}

Table 1shows the effect of viral inoculum and time of inoculation on the percentage virus disease 
severity. The result showed that significant differences $(P<0.05)$ occurred between single and mixed virus infection and the time of inoculation of the virus, compared to the control (non-inoculated plants). At 3 WAI, the significantly highest virus severity of 6.2 was recorded on plants mixed-inoculated with BICMV and CYMV at 2 WAP. This value was however not significantly different $(P>0.05)$ with the mixed inoculation of $\mathrm{BICMV}+\mathrm{CYMV}$ at $4 \mathrm{WAP}$ (5.6), and the single inoculation with BICMV at 2 WAP (5.1). At the 4 to 8 WAI, a consistent trend emerged, showing virus severity to be significantly highest in mixed infection of BICMV and CYMV at 2 WAI. The table also, indicated that early viral infection was more pathogenic irrespective of the virus involved. At the $5 \mathrm{WAI}$, it could be seen that virus severity was significantly highest for BICMV(7.7) and CYMV(7.3) inoculated at 2 WAP. The results indicated that mixed infections with BICMV and CYMV at 2 WAP were more pathogenic.

Table 1: Effect of Viral Inoculum and Time of Inoculation on Percentage Virus Severity

\begin{tabular}{|c|c|c|c|c|c|c|c|}
\hline $\begin{array}{l}\text { Virus/Time } \\
\text { Inoculation }\end{array}$ & 2wks & 3wks & 4wks & 5wks & 6wks & $7 w k s$ & 8wks \\
\hline BICMV@2wks & 2.6 & $5.1 \mathrm{ab}$ & $6.0 \mathrm{c}$ & $7.7 \mathrm{c}$ & $9.8 \mathrm{c}$ & $13.4 \mathrm{~b}$ & $14.3 \mathrm{~cd}$ \\
\hline BICMV@ @wks & 2.4 & $4.4 \mathrm{bc}$ & $4.7 e$ & $6.9 d$ & 8.3de & 10.6de & 12.2ef \\
\hline CYMV@2wks & 2.5 & $4.6 \mathrm{~b}$ & $5.1 \mathrm{~cd}$ & $7.3 \mathrm{c}$ & $9.6 \mathrm{c}$ & $12.0 \mathrm{c}$ & $13.4 d$ \\
\hline CYMV@4wks & 2.2 & $3.2 \mathrm{~cd}$ & $3.8 \mathrm{fg}$ & $6.7 d$ & $7.9 e$ & $9.8 \mathrm{ef}$ & $11.9 \mathrm{fg}$ \\
\hline $\begin{array}{l}\text { BICMV+ CYMV } \\
@ 2 w k s\end{array}$ & 2.9 & $6.2 a$ & $8.6 a$ & $10.3 a$ & $12.2 \mathrm{a}$ & $14.1 \mathrm{a}$ & $16.6 \mathrm{a}$ \\
\hline BICMV+ CYMV@4wks & 2.8 & $5.6 a b$ & $7.3 b$ & $9.4 b$ & $11.4 b$ & $13.6 \mathrm{~b}$ & $15.8 b$ \\
\hline Control & 2.6 & $2.9 d$ & $3.1 \mathrm{~g}$ & $4.8 \mathrm{e}$ & $6.4 f$ & $8.6 f$ & $10.1 \mathrm{~g}$ \\
\hline S.E.D & 0.11 & 0.38 & 0.60 & 0.62 & 0.53 & 1.19 & 1.76 \\
\hline
\end{tabular}

Means within a column followed by the same letter(s) are not significantly different using New Duncan Multiple Range Test at $\mathrm{P}=0.05$ 


\section{Effect on Plant Height}

Table 2 showed the effect of the treatments on cowpea plant height. The effect of viral inoculations caused a general stunting in the plants compared with the non inoculated plants. The results further showed that mixed infection with BICMV and CYMV at 2 WAP caused the most stunted growth while single inoculation with CYMV at 4 WAP produced the tallest of the virus inoculated plants. At 6 WAI, it could be seen that, plants singly inoculated with CYMV at 4 WAP had the significantly tallest plants with the mean height of $30.6 \mathrm{~cm}$. On the other hand, plants that had mixed virus infections, were the significantly shortest $(22.2 \mathrm{~cm})$. The trend was continuous till the 8 WAI.

Table 2: Effect of Viral Inoculum and Time of Inoculation on Plant Height (cm)

\begin{tabular}{lccccccc}
\hline Virus/Time Inoculation & 2wks & 3wks & 4wks & 5wks & 6wks & 7wks & 8wks \\
\hline BICMV @ 2wks & 9.7 & $10.5 \mathrm{~d}$ & $12.4 \mathrm{~d}$ & $17.3 \mathrm{~d}$ & $25.8 \mathrm{c}$ & $27.6 \mathrm{~d}$ & $29.2 \mathrm{e}$ \\
BICMV @ 4wks & 9.9 & $11.2 \mathrm{c}$ & $13.9 \mathrm{c}$ & $19.7 \mathrm{c}$ & $30.3 \mathrm{~b}$ & $31.9 \mathrm{c}$ & $38.8 \mathrm{c}$ \\
CYMV @ 2wks & 9.8 & $11.0 \mathrm{c}$ & $13.3 \mathrm{c}$ & $19.2 \mathrm{c}$ & $27.3 \mathrm{c}$ & $30.4 \mathrm{c}$ & $33.9 \mathrm{~d}$ \\
CYMV @ 4wks & 9.3 & $12.4 \mathrm{~b}$ & $17.5 \mathrm{~b}$ & $22.8 \mathrm{~b}$ & $30.6 \mathrm{~b}$ & $37.2 \mathrm{~b}$ & $40.0 \mathrm{~b}$ \\
BICMV+ CYMV @2wks & 9.4 & $10.2 \mathrm{~d}$ & $11.4 \mathrm{e}$ & $13.7 \mathrm{f}$ & $19.0 \mathrm{e}$ & $22.6 \mathrm{e}$ & $24.1 \mathrm{~g}$ \\
BICMV+ CYMV@4wks & 9.6 & $10.2 \mathrm{~d}$ & $12.2 \mathrm{~d}$ & $14.9 \mathrm{e}$ & $22.2 \mathrm{~d}$ & $23.3 \mathrm{e}$ & $25.9 \mathrm{f}$ \\
Control & 9.7 & $14.3 \mathrm{a}$ & $19.5 \mathrm{a}$ & $28.6 \mathrm{a}$ & $34.7 \mathrm{a}$ & $41.7 \mathrm{a}$ & $48.9 \mathrm{a}$ \\
& & & & & & & \\
S.E.D & 0.28 & 0.27 & 0.30 & 0.52 & 0.78 & 0.74 & 0.58 \\
\hline
\end{tabular}

Means within a column followed by the same letter(s) are not significantly different using New Duncan Multiple Range Test at $\mathrm{P}=0.05$

\section{Effect on Number of Leaves}

Table 3 showed the effect of the viral inoculums and time of inoculation on number of leaves per plant. The lowest numbers of leaves per plant were recorded in plants mixed inoculated with BICMV and CYMV at 2 and 4 WAP. Single virus inoculation however, resulted in significantly higher number of cowpea leaves, especially at the 4 WAP. The result showed that at the 6 WAI, while the mean number of leaves for 
control plants was 24.3 , single inoculation with CYMV at 4 WAP had a mean of 15.3 leaves per plant, while the lowest number of leaves per plant was in mixed infection at 2 WAP (7.1). The observation followed the same trend up to 8 WAI.

Table 3: Effect of Viral Inoculum and Time of Inoculation on Number of Leaves per Plant

\begin{tabular}{|c|c|c|c|c|c|c|c|}
\hline $\begin{array}{l}\text { Virus/Time } \\
\text { Inoculation }\end{array}$ & 2wks & $3 w k s$ & 4 wks & 5wks & 6wks & $7 w k s$ & $8 w k s$ \\
\hline BICMV @ 4wks & 2.0 & $6.1 b c$ & $10.3 \mathrm{c}$ & $11.7 \mathrm{c}$ & $13.5 \mathrm{c}$ & $15.4 \mathrm{~cd}$ & $17.0 \mathrm{c}$ \\
\hline CYMV@2wks & 2.1 & 4.3de & 8.6de & $9.3 d$ & $12.4 \mathrm{~cd}$ & 14.1cde & $16.9 \mathrm{~cd}$ \\
\hline CYMV@4wks & 2.2 & $7.6 \mathrm{~b}$ & $12.3 b$ & $12.8 b c$ & $15.3 b$ & $17.6 \mathrm{~b}$ & $20.0 \mathrm{~b}$ \\
\hline BICMV+ CYMV @2wks & 2.3 & $2.8 f$ & $4.6 \mathrm{~g}$ & $6.0 f$ & $7.1 f$ & $9.0 \mathrm{~g}$ & $12.7 f$ \\
\hline BICMV+CYMV@4wks & 2.2 & $3.5 \mathrm{e}$ & $6.4 f$ & $8.3 e$ & $10.6 \mathrm{e}$ & $12.0 f$ & 13.6ef \\
\hline Control & 2.1 & $10.3 a$ & $15.1 \mathrm{a}$ & $19.1 \mathrm{a}$ & $24.3 a$ & $26.8 \mathrm{a}$ & $28.2 \mathrm{a}$ \\
\hline S.E.D & 0.29 & 0.56 & 0.34 & 1.14 & 1.67 & 1.75 & 1.07 \\
\hline
\end{tabular}

Means within a column followed by the same letter(s) are not significantly different using New Duncan Multiple Range Test at $\mathrm{P}=0.05$.

\section{Effect on Yield parameters}

Table 4 showed the effect of treatments on some yield attributes such as the number of pods, pod weight per plant and seed weight per plant. The results show that viral inoculation caused a significant reduction in yield attributes compared with the non-inoculated plants. The control plants had the highest yield parameters. However, inoculation assessment indicated that, mixed viral inoculation with BICMV and CYMV at 2 WAP produced the highest reduction in the yield parameters considered. The number of pods per plant, pod weight per plant and seed weight per plant for the treatment were $1.7,1.6 \mathrm{~g}$ and $1.1 \mathrm{~g}$ respectively. In contrast, single viral inoculation with CYMV at 4 WAP produced significantly higher yield values of 8.3 pods per plant, mean pod weight of $13.6 \mathrm{~g}$ and mean seed weight of $10.1 \mathrm{~g}$ per plant. 
Table 4: Effect of Viral Inoculum and Time of Inoculation on Yield

\begin{tabular}{llll}
\hline $\begin{array}{l}\text { Virus/Time } \\
\text { Inoculation }\end{array}$ & $\begin{array}{l}\text { No of } \\
\text { pods @8wks }\end{array}$ & Pod wt/plant(g) & Seed wt/plant(g) \\
\hline BICMV @ 4wks & $6.3 \mathrm{c}$ & $9.8 \mathrm{c}$ & $6.1 \mathrm{c}$ \\
CYMV @ 2wks & $6.0 \mathrm{c}$ & $7.6 \mathrm{~d}$ & $4.5 \mathrm{~d}$ \\
CYMV @ 4wks & $8.3 \mathrm{~b}$ & $13.6 \mathrm{~b}$ & $10.1 \mathrm{~b}$ \\
BICMV+CYMV@2wks & $1.7 f$ & $1.6 \mathrm{~g}$ & $1.1 \mathrm{~g}$ \\
BICMV+CYMV@4wks & $3.3 \mathrm{e}$ & $2.4 f$ & $2.3 f$ \\
Control & $13.4 \mathrm{a}$ & $17.6 \mathrm{a}$ & $13.9 \mathrm{a}$ \\
& & & \\
S.E.D & 0.51 & 0.27 & 0.28 \\
\hline
\end{tabular}

Means within a column followed by the same letter are not significantly different using New Duncan Multiple Range Test at $\mathrm{P}=0.05$.

\section{DISCUSSION}

In the management of virus diseases, the use of host plant resistance is considered to be the most economical and environmentally friendly (Byoung-Cheorl et al. 2005). This study showed that cowpea variety Ife brown, was susceptible to BICMV and CYMV either as single or as mixed virus infections. These virus diseases have, at one time or the other, been found to affect cowpea production in Nigeria resulting in poor yields (Shoyinka et al., 2005). The study also showed that mixed infection with BICMV and CYMV were more pathogenic than single viral inoculation. Zhang et al., (2000 and 2001), had reported that viral interactions and coinfection with two independent unrelated viruses resulted in a much more serious disease than either virus in a single infection. This situation is often referred to as synergism (Fondong et al., 2000). The results of the present study therefore suggests that the higher viral infection, culminating in significant growth and yield reductions in the mixed infected plants, was due to the synergistic interactions between BICMV and CYMV. This is in agreement with Wintermantel, (2005); Murphy and Bowen,(2006,) that multiple viral infections resulted in more serious diseases and a greater reduction in growth and yield parameters than single viral infections.

Generally, the age of plant at the time of viral infection have quantitative and qualitative effects on cowpeas (Taiwo and Akinjogunla, 2006). The results from the study shows that inoculation at an early plant 
age (2WAP), resulted in a higher virus severity and lower growth and yield parameters than inoculation at a later age (4WAP). This could be due to the fact that plants at 4WAP were more matured and had some measure of tolerance to the viruses. Plants inoculated at 2WAP, are much younger and thus more susceptible to virus diseases. These results agree with Langham et al, (2005), which indicated that the younger the plants at the time of infection, the more severe the disease symptoms and the greater the effects on yield.

\section{CONCLUSION}

This study has confirmed the susceptibility of cowpea (cv. Ife-Brown) to BICMV and CYMV and showed that infection by the viruses at an early plant age was more pathogenic. The study further proved that the synergistic effect of BICMV and CYMV on cowpea elicited a higher virus severity than single virus infection.

There is therefore, the need for urgent research into the mechanism of plant viral synergism and the extent to which such interactions impact plants in nature. Also, cowpea varieties resistant to BICMV and CYMV are warranted to prevent viral infections and improve cowpea productivity.

\section{ACKNOWLEDGEMENT}

We wish to sincerely thank Dr. L. Kumar of IITA-Ibadan, for providing the viral inoculums used in the study.

\section{REFERENCES}

Aliyu, T.H., Balogun, O.S. and Kumar, L. (2012). "Survey of the symptoms and viruses associated with cowpea (Vigna unguiculata (L).) in the Agroecological zones of Kwara State, Nigeria". Ethiopian Journal of Environmental Studies and Management (EJESM) 5:(4)613-619.

Asiwe, J.A.N., Belane, A, and Dakora, F.D. (2009). Evaluation of cowpea breeding lines for nitrogen fixation at ARC-Grain Crops Institute, South Africa. Paper presented at the $16^{\text {th }}$ International Congress on Biological Nitrogen Fixation. Montana, USA, 14-19 June, 2009.

Balogun, O.S. (2000). Studies on host-pathogen interactions in tomato under mixed infections with potato $X$ potexvirus and tobacco mosaic tobamovirus. A doctoral dissertation submitted to Tokyo University of Agric and Tech. Japan for the award of Ph.D in Biological Production (Phythopathology) 174 pages.

Bashir, M., Ahmad, Z. and Murata, N. (2000). Seed-borne Viruses: Detection, Identification and Control. Pakistan agricultural Research Council, National Agricultural Research Center, Islamabad, Pakistan,pp:156.

Bashir, M., Ahamad, Z. and Ghafoor, . A. (2002). "Cowpea aphid-borne mosaic potyvirus: a review". International Journal of Pest Management 48:155168.

Byoung-Cheorl, K., Yeam, I. and Jahn, M.M. (2005) "Genetics of plant virus resistance". Annual Review of Phytopathology 43:581621. 
Davis, D.W., Oelke, E.A., Ophinger, E.S., Doll, J.D., Hanson, C.V. and Putnam, D.H. (1991). Cowpea. University of Wisconsin-Madison, USA. 1-10.

Fondong, V.N., Pita, J.S., Rey, M.E.C., De Kochko, A., Beachy, R.N. and Fauquet, C.M. (2000). "Evidence of synergism between African cassava mosaic virus and a new double-recombinant geminivirus infecting cassava in Cameroon". Journal of General Virology 81:28797.

Froissart, R., Michalakis, Y. and Blanc, S. (2003) "Helper-component transcomplementation in the vector transmission of plant viruses". Phytopathology 92: 576579.

Hampton, R.O., Thottappilly, G. and Rossel, H.W. (1997). "Viral diseases of cowpea and their control by resistance conferring genes". In: B.B. Singh, D.R.Mohan Raj, K.E.Dashiell and L.E.N. Jackai (eds.). Advances in Cowpea Research 3: 159-175.

Hull, R. (1977). "The banding behaviour of the virus of Southern bean mosaic virus group in gradient of caesium sulphate". Virology 79:50-57.

Khan, J. A., Lohuis, H., Goldbach, R.W. and Dijkstra, J. (1994). "Distribution and localization of bean common virus and bean black root virus in stems of doubly infected bean plants". Archives of Virology 138: 95-104.

Langham, M.A.C., Cihlar-Strunk, C.L., Hoberg, A.E. (2005). "Evaluation of high pressure spray inoculation of bean pod mottle virus on yield and test weight of soybean". Phytopathology 95:S164.

Méndez-Lozano, J., Torres-Pacheco, I., Fauquet, C.M. and Rivera-Bustamante, R.F. (2003). "Interactions between geminiviruses in a naturally occurring mixture: Pepper huasteco virus and Pepper golden mosaic virus". Phytopathology 93: 270-277.

Murphy, J.F, and Bowen, K.L. (2006). "Synergistic disease in pepper caused by the mixed infection of Cucumber mosaic virus and Pepper mottle virus". Phytopathology 96:240-247.

Owolabi, A.T., Taiwo, M.A., and Mabadeje, S. A. (1988). "Effects of single and mixed inoculations with blackeye cowpea mosaic virus on two Nigerian cowpea cultivars". Nigerian Journal of Basic and Applied Sciences 2:25-33.

Pruss, G., Xin, G., Xing, M. S., Carrington, J.C. Vancea,V. B. (1997)."Plant Viral Synergism: The Potyviral Genome Encodes a Broad-Range Pathogenicity Enhancer That Transactivates Replication of Heterologous Viruses". The Plant Cell 9: 859-868.

Sakai, E., Dawson, J.R.O., and Watts, J.W. (1983). "Interference in infections of tobacco protoplasts with bromoviruses". Journal of General virology 64:1347-1354.

Shoyinka, S.A., Ittah, M.A., Fawole, I. and Hughes, J.A. (2005). Sources of resistance to seed transmission and variation in responses of cowpea varieties to infection by four seed-borne viruses http://wwwAfrican crops. Net/breeding\%200abstracts/breeding\%20shoyinka.hnt .

Summerfield, R.J. and Roberts, E.H. (1985). Grain legume crops. Collins, London. 1-6.

Taiwo, M. A. and Akinjogunla O. J. (2006). "Cowpea viruses: Quantitative and qualitative effects of single and mixed viral infections". African Journal of Biotechnology 5(19):1749-1756.

Thottappilly, G, and Rossel, H.W. (1992). Virus diseases of cowpea in tropical Africa. Tropical Pest Management 38:337-348. 
Timko, M.P., Ehlers, J.D. and Roberts, P.A. (2007). Cowpea. In: Pulses, Sugar and Tuber Crops, Genome Mapping and Molecular Breeding in Plants (Kole C, ed.). (3). Springer-Verlag, Berlin, Heidelberg, 49-67.

Valenzuela, H. And Smith, J. (2002). Cowpea. College of Tropical Agriculture and Human Resources. University of Hawaii at Monoa, Honolulu, Hawaii. Pp1-4.

Vanitharani, R., Chellappan, P., Pita, J.S., Fauquet, C.M. (2004). "Differential roles of AC2 and AC4 of cassava geminiviruses in mediating synergism and suppression of post-transcriptional gene silencing". Journal of Virology 78: 9487-9498.

Wintermantel, W.M. (2005). "Co-infection of Beet mosaic virus with beet yellowing viruses leads to increased symptom expression on sugar beet". Plant Disease 89:325-331.

Zhang, X.S., Holt, J. and Colvin, J. (2000). "Mathematical models of host plant infection by helperdependent virus complexes: why are helper viruses always avirulent?" Phytopathology 90: 8593.

Zhang, X.S., Holt, J. and Colvin, J. (2001). "Synergism between plant viruses: a mathematical analysis of the epidemiological implications". Plant Pathology 50(6):732-746. 